\title{
Physical activity and disability - A dichotomy in the space of personal security
}

\author{
Remigiusz Dróżdż
}

Gdansk University of Physical Education and Sport in Gdansk, Poland

\section{abstract}

Background: Out of the three cognitive categories that are crucial to the formulation of the problem addressed in this article, physical activity and disability as well as personal security have been the subject matter of numerous scientific analyses, but there are very few references associating them with one another. The aim of this article is to interpret the current state of knowledge concerning each of these fields as well as to assess the bibliographic resource relating to their integral inclusion.

Material and methods:

A query of foreign and Polish monographs as well as scientific periodicals, available both in traditional and electronic form, was adopted as the research method. In terms of time, the presented state of research works refers to spring 2021.

Results: Analyses of the relationship between personal security and physical activity are available primarily in the context of creating confidence, improved quality of life and well-being. Associations between personal security and disability minimally relate to the concurrent physical activity.

Conclusions: The results of source analysis argue for the need to promote research projects on the sense of personal security among those with disabilities who engage in physical activity and those who avoid it.

Key words: physical activity, disability, personal security.

\section{article details}

Article statistics: Word count: 1,814; Tables: 0; Figures: 0; References: 29

Received: June 2021; Accepted: October 2021; Published: November 2021

Full-text PDF: http://www.balticsportscience.com

Copyright @ Gdansk University of Physical Education and Sport, Poland

Indexation: Celdes, Clarivate Analytics Emerging Sources Citation Index (ESCI), CNKI Scholar (China National Knowledge Infrastructure), CNPIEC, DOAJ, EBSCO - Central \& Eastern European Academic Source, EBSCO - SPORTDiscus, EBSCO Discovery Service, Google Scholar, Index Copernicus, J-Gate, Naviga (Softweco, Primo Central (ExLibris), ProQuest - Family Health, ProQuest - Health \& Medical Complete, ProQuest - Illustrata: Health Sciences, ProQuest Nursing \& Allied Health Source, Summon (Serials Solutions/ProQuest, TDOne (TDNet), Ulrich's Periodicals Directory/ ulrichsweb, WorldCat (OCLC)

Funding: This research received no specific grant from any funding agency in the public, commercial, or not-for-profit sectors. Author has declared that no competing interest exists.

Corresponding author: Remigiusz Dróżdż, Gdansk University of Physical Education and Sport, 80-336 Gdansk,Gorskiego 1, Poland; e-mail: remigiusz.drozdz@awf.gda.pl

Open Access License: This is an open access article distributed under the terms of the Creative Commons Attribution-Non-Commercial-NoDerivatives 4.0 International (https://creativecommons.org/licenses/by-nc-nd/4.0/), which permits use, distribution, and reproduction in any medium, provided the original work is properly cited, the use is non-commercial and is otherwise in compliance with the license. 


\section{INTRODUCTION}

In terms of a sense of security, the issues of physical activity and disability can be, and usually are, seen as two opposing categories. According to A. Maslow [1], security is one of the most important human needs without which a human being encounters difficulties on the way to fulfil other needs or, in extreme cases, does not fulfil them at all. Security is interpreted by him based on the senses and instinctive reactions. From the point of view of an individual, the sense of security is subjective, and, as a rule, the level of feeling it evidences the awareness of a real threat, sometimes, however, a false awareness of a threat, despite its absence. Among people with disabilities, due to the assumed lower level of sense of security compared to non-disabled members of the society, it seems more frequent to avoid the threat or to give in to it [2].

However, the analysed group, regardless of the fact whether it is affected by limitations in the physical or mental sphere, has a chance to modify their reactions to threats occurring in their lives. Systematically undertaken physical activity may be an important element of support in this space. It increases self-confidence, develops psychological resilience as well as determination and reduces the risk of disease, significantly affecting the quality of life [3]. Therefore, a positive correlation between the extent of physical activity and the sense of personal security can also be assumed. Security achieved in this way strictly relates to an increased assessment of one's own physicality, both in terms of physical appearance and sporting competence [4]. In view of the above, the standard pattern of behavioural response to emerging threat can be supplemented in physically active disabled people by eliminating the source of the threat or ignoring it, which involves risk-taking.

The outlined issues may indicate opposite effects in shaping the sense of security in persons with disabilities and physically active persons. The collected research material is to provide evidence confirming the effect of strengthening the sense of security in the course of undertaken physical activity and the effect of its limitation in everyday functioning in the sense of one's own disability. At the same time, it seems important to analyse the available literature on the possibilities of restoring the sense of security in the disabled in the process of their physical improvement. This would allow us to confirm the assumption that acquired or congenital disability does not have to be accompanied by a disturbed sense of security.

\section{PHYSICAL ACTIVITY AND THE SENSE OF SECURITY}

The sense of security is usually correlated with a high level of self-confidence, manifested by the belief that one can succeed in one's own actions, in the face of successive demands and obstacles. It is important to achieve a state of confidence advanced enough to overcome the difficulties encountered, but at the same time low enough to be aware of the need for continuous improvement [5]. Confidence can be considered as a situation-specific state or as a permanent feature of athlete's disposition. In both cases, it is possible to train it. By working on specific sporting situations, where a lack of confidence is apparent, it can be induced and developed, while strengthening the sense of security at the same time.

There are different aspects related to sports self-confidence [6]. The first refers to selfconfidence manifested in the belief and conviction in one's own skills or capabilities. In the light of the activities that have already been undertaken, this is complemented by a sense of self-efficacy and finally self-esteem, meaning the overall self-esteem and attitude towards oneself. Self-confidence of athletes positively influences attention, arousal control, positive emotions and the success of starting strategies. Confidence in the success of an activity is associated with the achievement of the desired result and the lack of confidence is seen as a source of failure. Although self-confidence does not guarantee success during competition, it helps athletes to cope with difficult situations [7]. 
Among the factors that affect self-confidence of an athlete and increase the sense of security, apart from the level of performance of given skills, there is also the broadly defined social climate. It is formed by: support from others, coach's style and environmental conditions. As the years go by, self-regulation becomes more and more important, expressed in mental preparation, experience of previous starts and finally the feeling of optimal performance at a given moment [8]. Thus understood training can have a direct impact on sports performance by eliminating symptoms of self-limitation [9], negative emotions [10], especially stress [11] and anxiety [12]. These are important determinants of good sports performance [13].

In the context of undertaken physical activity, mood also improves. The awareness of one's own increasing fitness, physique, the possibility of participating in physical activity with others and making new friends become, for some, more important than the physical benefits of an active lifestyle [14].

\section{DISABILITY AND THE SENSE OF SECURITY}

Disability and the resulting loss of health have a number of consequences, both on an individual and social level. Disturbance or a complete loss of the sense of security seems to be particularly dangerous. It is then difficult and sometimes even impossible to fulfil socially recognised functions and establish as well as maintain satisfactory interpersonal relations. Problems with using the individual developmental potential are strengthened by limited acquisition of knowledge and skills that facilitate coping with difficult situations [15].

A fundamental element of personal security is, in the case of a disabled person, the sense of stability. For people struggling with various forms of disability, it is extremely important to maintain order, repetitiveness of events, constant patterns and rituals during everyday activities. Unsteadiness, chaos and randomness can be the source of many negative emotions, such as anxiety, fear or sense of threat. A positive effect of respecting the need for stability is the sense of self-confidence, treated as self-affirmation, which manifests itself in relationships with other people.

Referring to the conclusions from undertaken observations [16], a considerable number of people with disabilities show deficits in the area of personal security. They fight internal battles, making it difficult for them to function, depreciating their own person and evoking a range of pejorative emotions. Disability becomes, in their case, the main axis of evaluation of their own competences, achievements and aspirations. Sadness, anxiety, intimidation, sense of inferiority, but also anger or bitterness are just some of the affective states that accompany them every day. Disturbances in the sphere of the sense of closeness, the sense of stability or the sense of self-confidence cause deprivation of the need for security. It disorganises their lives and activities and makes them perceive the world as a dangerous place that prevents them from implementing their plans and intentions. In difficult situations, defence mechanisms are activated, the essence of which is relying exclusively on previously learned ways of reacting. Thus, there is no place here for the acquisition of competence in new reactions adequate to changing conditions [17]. Schematic, ritualised reactions to new circumstances are not conducive to individual development which is a constitutive determinant of security. The permanent lack of satisfaction of this need result $\mathrm{s}$ in the formation of a fixed syndrome of insecurity in the disabled [18].

Foreign reports appearing over the last few decades are an important supplement of the problems undertaken by Polish researchers. Already in the early 1950s, it was pointed out that people with disabilities have problems with adapting to life in a society that stigmatises anyone who does not fit the description of normal individuals. This led Cusforth [19] to conclude that society's negative reaction to disabled people was the exclusive reason for their emotional problem. Subsequent research, however, suggested that a disabled person 
could nevertheless rise from a lower level of self-acceptance to a higher one as a result of social conditions, technical changes or trends that favour equal life opportunities [20]. As a rule, these opportunities are not fully exploited, as self-perception of disability is invariably accompanied by disturbed self-esteem and high level of depression, stress and anxiety [21].

\section{PHYSICAL ACTIVITY IN DISABILITY AND THE SENSE OF SECURITY}

Promoting physical activity adjusted to people with disabilities has been the subject of several studies to date [22, 23]. Among the different possibilities of inclusive activities, sporting activity represents an effective alternative, considering the social and physical aspects as well as the positive psychological effect usually reported by the participants $[24,25]$. These benefits were manifested through the enhancement of functional abilities, the development of relationships and increased self-esteem $[26,27]$ and, ultimately, higher perception of the quality of life [28].

In 2006, an anonymous survey was conducted among athletes with and without disabilities in Lithuania [29]. A total of 235 questionnaires were analysed, out of which 159 were filled in by people with disabilities and 76 by people without disabilities. More than half of the respondents without disabilities indicated that their lives were meaningful, while among the athletes with disabilities this percentage was only $34 \%$. As many as $59 \%$ of the respondents without disabilities were satisfied with their quality of life, compared to $36.2 \%$ of the respondents with disabilities. More than half of the athletes without disabilities said that sport played an important role in their lives, while this percentage was much lower among the athletes with disabilities. None of the cognitive aspects mentioned referred directly to the sense of personal security, which encourages future exploration of this field.

\section{CONCLUSION}

Security is the basis of proper human development, undertaking new challenges and coping with adversities. It makes it possible to establish satisfying relations with other people and to implement one's own plans and intentions. For these and many other reasons, security is treated as one of the most important human psychological needs. When one is deprived of this, it entails a number of negative consequences in both physical and psychological dimensions.

Disability and its consequences undoubtedly affect the sense of security in a person. Moreover, healthy people often deny the disabled people's right to life, development, freedom and love. They treat the disabled as objects, refuse to cooperate with them, repeat stereotypes and create architectural, economic and educational barriers. This is all the more dangerous because the sense of security, self-esteem and self-acceptance, which are the result of, among other things, other people's actions, constitute the foundation for the improvement of every person deviating from the commonly accepted norm.

It is, therefore, an important task for the society as a whole to identify basic factors affecting the sense of security in the disabled in public spaces. Sporting activity may be considered as one of these factors. As there is little research activity in this area, it is worth planning new research projects in the field of physical culture, which, apart from drawing more social attention to the problem of security in people with disabilities, could result in their increased self-acceptance and lifelong activity.

\section{REFERENCES}

[1] Maslow AH. A Theory of Human Motivation. Psychol Rev. 1943;50(4):370-396. https://doi.org/10.1037/h0054346

[2] Hohfreiter L. Wstęp do studiów bezpieczeństwa [Introduction to security studies]. Kraków: Oficyna wydawnicza AFM Krakowskie Towarzystwo Edukacyjne; 2012. Polish 
[3] Żukowski R. Edukacyjne i wychowawcze wartości sportu w refleksji pedagogicznej i w ocenie młodzieży [Educational and educational values of sport in pedagogical reflection and evaluation of young people]. In: Kaźmierczak A Maszorek-Szymala A, Dębowska E, Eds. Kultura fizyczna izdrowotna współczesnego człowieka - teoretyczne podstawy i praktyczne implikacje. Łódź: UŁ; 2008, 24-33. Polish.

[4] Rosenberg M. Society and the adolescent self-image. New York: Princeton University; 1965. https://doi. org/10.1515/9781400876136

[5] Hays K, Thomas O, Maynard I, Bawden M. The role of confidence in world-class sport performance. J Sport Sci 2009;27:1185-1199. https://doi.org/10.1080/02640410903089798

[6] Hays K, Maynard I, Thomas O, Bawden M. Sources and types of confidence identified by world class performers. J Appl Sport Psychol. 2007;19:434-456. https://doi.org/10.1080/10413200701599173

[7] Short SE, Ross-Stewart L. A review of self-efficacy based interventions. In: Advances in applied sport psychology: A review. Mellalie SD, HantonS. Eds. United Kingdom: Routledge; 2009, 221-280.

[8] Mellalieu SD, Hanton S, Fletcher D. A competitive anxiety review: Recent directions in sport psychology research. In: Literature reviews in sport psychology. Hanton S, Mellalieu SD. New York: Nova Science; 2006, 1-45.

[9] Coudevylle G, Ginis K, Famose J. Determinants of self-handicapping strategies in sport and their effects on athletic performance. Soc Behav Personal Int J. 2008;36(3):391-398. https://doi.org/10.2224/sbp.2008.36.3.391

[10] Kouli O, Bebetsos E, Kamperis I, Papaioannou A. The relationship between emotions and confidence among Greek athletes from different competitive sports. Kinesiology. 2010;42(2):194-200.

[11] Morse A, Walker R, Monroe D. The Effect of Exercise on a Psychological Measure of the Stress Response. Wellness Perspectives 1994; 11(1): 39-46.

[12] Chamberlain ST, Hale BD. Competitive state anxiety and self-confidence: Intensity and direction as relative predictors of performance on a golf putting task. Anxiety Stress Cop. 2007;20(2):197-207. https://doi. org/10.1080/10615800701288572

[13] Beattie S, Hardy L, Woodman T. Precompetition self-confidence: The role of the self. J Sport Exerc Psychol. 2004 26;427-441. https://doi.org/10.1123/jsep.26.3.427

[14] Serfass RC, Gerbarich SG, Exercise for optimal health: strategies and motivational considerations. Prevent Med. 1984;13:79-99. https://doi.org/10.1016/0091-7435(84)90042-2

[15] Krzewniak D. Bezpieczeństwo osób niepełnosprawnych [Security of desabled persons]. De Securitate et Defensione. O Bezpieczeństwie i Obronności2015;1:89-100. Polish.

[16] Mellibruda J. Być dobrym dla samego siebie - o sztuce stawania się swoim przyjacielem [Being good to yourself about the art of becoming your friend]. http://www.psychologia.edu.pl/dziupla-jurka/teksty/1371-byc-dobrym-dlasamego-siebie-o-sztuce-stawania-sie-swoim-przyjacielem.html Polish.

[17] Kałużna J. Poczucie bezpieczeństwa a zdrowie psychiczne człowieka. Biuletyn Okręgowej Izby Pielęgniarek i Położnych. 2011;1:17-19. Polish.

[18] Uchnast Z. Metoda pomiaru poczucia bezpieczeństwa. In: Wykłady z psychologii w KUL 1990; 5: 95-108. Polish.

[19] Cusforth Z. Academic value of research participation by undergraduates. Am Psychol. 1951;41:317. https://doi. org/10.1037/0003-066X.41.3.317.a

[20] Jennings J. Influence of television commercials on women's self-confidence and independence judgment. J Personal Soc Psychol. 1988; 38: 203-210. https://doi.org/10.1037/0022-3514.38.2.203

[21] Mushtaq S, Akhouri D. Self Esteem, Anxiety, Depression and Stress among Physically Disabled People. International J Indian Psychol. 2016;3(4),64:125-132. https://doi.org/10.25215/0304.128

[22] Barak S, Hutzler Y, Dubnov-Raz G. Physical exercise for people with cerebral palsy: effects, recommendations and barriers. Harefuah. 2014;153(5):266-272.

[23] Jaarsma EA, Dijkstra PU, Geertzen JHB, Dekker R. Barriers to and facilitators of sports participation for people with physical disabilities: A systematic review. Scand J Med Sci Sports. 2014;24(6):871-881. https://doi.org/10.1111/ sms.12218

[24] Blauwet C, Willick SE. The Paralympic Movement: using sports to promote health, disability rights, and social integration for athletes with disabilities. PM \& R 2012;4(11):851-856. https://doi.org/10.1016/j.pmrj.2012.08.015

[25] Yazicioglu K, Yavuz F, Goktepe AS, Tan AK. Influence of adapted sports on quality of life and life satisfaction in sport participants and non-sport participants with physical disabilities. Disabil Health J. 2012;5(4):249-253. https://doi. org/10.1016/j.dhjo.2012.05.003

[26] Wilhite B, Shank J. In praise of sport: promoting sport participation as a mechanism of health among persons with a disability. Disabil Health J. 2009;2(3):116-127. https://doi.org/10.1016/j.dhjo.2009.01.002

[27] Pereira R, Osborne R, Pereira A, Cabral SI. The importance of high performance sports in social inclusion of blind people: A study centered on Benjamin Constant Institute - Brazil. Motricidade. 2013;9(2):94-105. https://doi. org/10.6063/motricidade.9(2).2671

[28] Laferrier JZ, Teodorski E, Cooper RA. Investigation of the impact of sports, exercise, and recreation participation on psychosocial outcomes in a population of veterans with disabilities: A cross-sectional study. Am J Phys Med Rehabil. 2015;94(12):1026-1034. https://doi.org/10.1097/PHM.0000000000000263

[29] Samsonienè L, Baubinas A, Adomaitienè R, Jankauskienè K, Korotkich I, Kèvelaitis E. Quality of life of athletes with disability and some aspects of equal possibilities. Medicina (Kaunas). 2010;46(3):211-218. https://doi.org/10.3390/ medicina46030030

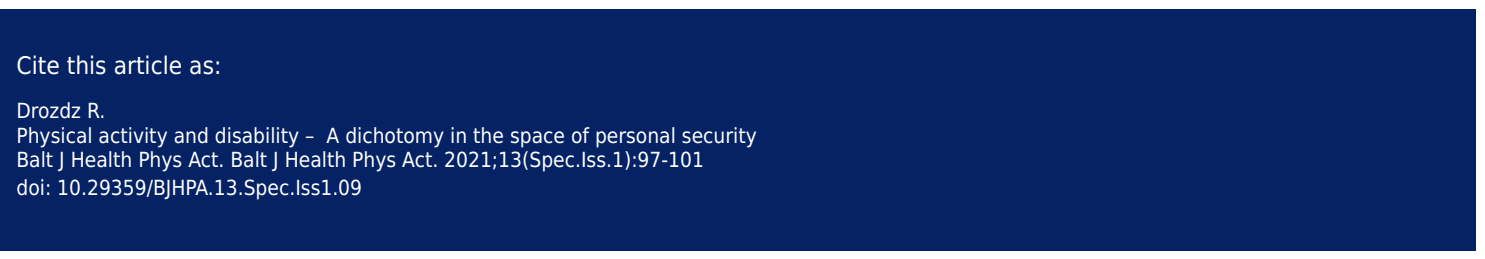

